\title{
PERBANDINGAN SIKAP TERHADAP PERILAKU SEKS PRANIKAH ANTARA SISWA SMAN DENGAN SISWA MAN
}

\author{
Raden Reny Indrawaty \\ Fakultas Psikologi UIN Sunan Gunung Djati Bandung, Jl. A.H Nasution No. 105 Bandung \\ email: raden.reny@ telkom.net
}

\begin{abstract}
Abstrak
Penelitian ini berawal dari ketertarikan peneliti untuk melihat perbedaan sikap siswa SMA dan Madrasah Aliyah terhadap perilaku seks pranikah. Ketertarikan ini didukung oleh indikasi yang menunjukkan adanya peningkatan persentase remaja yang melakukan hubungan seks pranikah. Jika dilihat dari segi kurikulum pelajarnya, kurikulum SMA jelas berbeda dengan kurikulum Madrasah Aliyah. Perbedaan tersebut sangat mencolok pada kurikulum agamanya. Siswa-siswi SMA secara umum lebih banyak mengenyam pendidikan umum dan hanya sedikit saja jam pelajaran yang diberikan untuk pendidikan keagamaan, sedangkan siswa-siswi Madrasah Aliyah memperoleh pendidikan keagamaan yang berlebih. Penelitian ini menggunakan metode komparatif, hal tersebut dilakukan untuk mencari dan melihat derajat perbedaan, dengan menggunakan uji U Mann Whitney. Berdasarkan hasil perhitungan yang diperoleh dengan derajat kepercayaan sebesar $95 \%$ $(\alpha=0,05)$ diketahui bahwa $\mathrm{p} \geq \alpha$. Hal ini memiliki arti bahwa $\mathrm{H}_{\mathrm{o}}$ diterima dan $\mathrm{H}_{1}$ ditolak, sehingga dapat dikatakan bahwa tidak terdapat perbedaan sikap terhadap perilaku seks pranikah antara siswa SMAN "X" dengan siswa MAN "Y" Bandung. Namun demikian, hasil yang diperoleh menunjukkan bahwa rata-rata ranking sikap terhadap perilaku seks pranikah siswa MAN "Y" Bandung lebih besar dibanding siswa SMAN "X" (71,02 > $63,61)$.
\end{abstract}

Kata kunci: sikap, remaja dan perilaku seks pranikah

\section{Abstract}

The investigator feels interesting to know the differences attitude in SMA students and MA students to the pre marriage sex behavior. There is the indications shows that the adolescence attitude to the pre marriage sex is increasing. If we look the religion curriculum, there is the differences between the religion curriculum in SMA and MA. The students of SMA study religion much more than the students of MA. The research uses the comparative method and uses Mann Whitney $U$ test. Based on the counting the degree of trust is $95 \%(\alpha=0,05)$ known that $p \geq \alpha$. It means that $H_{o}$ is accepted and $H_{1}$ is rejected. From the result above shows that there is no attitude differences to the pre marriage sex behavior between the students at SMA and the students at MA. The average ranking between SMA and MA is 71,02 > 63,61.

Keywords: attitude, adolescence, and pre marriage sex 


\section{PENDAHULUAN}

Remaja merupakan individu yang sedang mengalami masa peralihan, dari segi kematangan biologis, seksual, sedang berangsur-angsur memperlihatkan karakteristik seks sekunder sampai mencapai kematangan seks, dari segi perkembangan psikologis, psikologisnya sedang berkembang dari sifat anak-anak menjadi dewasa. Dari segi sosial ekonomi ia adalah individu yang beralih dari ketergantungan, menjadi relatif mandiri. (WHO, 1974, dalam Sarwono, 2006: 9).

Mengingat bahwa usia remaja adalah usia yang sangat aktif termasuk aktif dalam dorongan dan perilaku seksualnya, yaitu dengan adanya pengaruh lingkungan seperti VCD dan buku/majalah yang bernuansa porno, munculnya trend hubungan seks bebas, kurangnya kontrol dari orang tua dalam menanamkan nilai kehidupan yang religius dan tersedianya prasarana untuk melakukan tindakan asusila membuat remaja semakin sulit mengambil keputusan mengenai perilaku seksual yang bertanggung jawab dan sehat.

Kematangan psikoseksual pada remaja perlu diperkuat untuk melindungi dirinya sendiri dari pengaruh lingkungan, yaitu dengan pemberian pembekalan pengetahuan tentang seksualitas yang sehat dan bertanggung jawab. Semakin meningkatnya perilaku seksual dan reproduksi di kalangan remaja menyebabkan semakin rentannya remaja terpapar oleh berbagai macam permasalahan kesehatan reproduksi. Sejalan dengan pengetahuan ilmu teknologi, serta makin derasnya informasi tentang seks yang memungkinkan ditangkap oleh semua lapisan masyarakat termasuk remaja, dimana remaja selalu ingin tahu dan mencoba hal yang belum pernah dilakukan serta sedang meningkatnya libido pada remaja, memungkinkan remaja menafsirkan dengan salah mengenai informasi seks tersebut yang memungkinkan remaja melakukan perilaku seks.

Remaja merupakan kelompok umur yang sangat rentan terhadap pengaruh lingkungan dan mereka lebih banyak menghabiskan waktunya berkumpul dengan teman dan kelompoknya. Remaja dengan segala karakteristiknya lebih terbuka dan suka berbagi dengan teman dari pada dengan orang tua yang cenderung protektif terhadap anaknya. Kesehatan reproduksi merupakan salah satu masalah yang banyak mempengaruhi remaja karena reproduksi yang sehat akan tercapai apabila remaja tersebut telah menjaga fungsi reproduksinya dari masa remaja. Masalah seksualitas dikalangan remaja adalah masalah yang cukup pelik untuk diatasi. Di satu sisi perkembangan seksual itu muncul sebagai bagian dari perkembangan yang harus mereka jalani. Namun, disisi lain, penyaluran hasrat seksual yang belum semestinya mereka lakukan menimbulkan kecemasan dan akibat yang serius, seperti kehamilan atau tertular penyakit kelamin. Berdasarkan kecemasan-kecemasan itulah, sejak tahun 1960-an, ketika mulai muncul revolusi seks di daratan Eropa dan Amerika, penelitian mengenai keserbabolehan dalam perilaku seksual pada remaja mulai dilakukan.

Ada indikasi yang menunjukkan adanya peningkatan persentase remaja yang memiliki tingkat keserbabolehan yang tinggi atau yang melakukan hubungan seks pranikah (Sarwono, 1989, dalam Etikariena). Tetapi penelitian-penelitian yang dilakukan menemukan hasil yang tidak konsisten mengenai tingkat keserbabolehan remaja dalam perilaku seks pranikah. Bahkan pada penelitian yang dilakukan pada tahun 1990-an menunjukkan kecenderungan adanya penurunan prosentase remaja, baik yang melakukan hubungan seks pranikah atau yang memiliki keserbabolehan tinggi terhadap perilaku seks pranikah (Ken Saraswati, 1993; Evy Syartika, 1998, dalam Etikariena).

Tinggi rendahnya keserbabolehan remaja dalam perilaku seksual ditentukan oleh banyak faktor. Salah satunya adalah dari informasi yang didapatkan oleh remaja mengenai hal-hal yang berkaitan dengan masalah seksual. Krecth \& Crutchfield (1958, dalam Etikariena) menyatakan bahwa sikap bisa terbentuk melalui informasi yang diterima oleh individu. Informasi mengenai masalah seks ini bisa diterima remaja melalui berbagai sumber. Biasanya, sumber dimana seseorang mendapatkan informasi adalah melalui lingkungan yang terdekat dengan dirinya. Untuk remaja, lingkungan yang dekat dengan keseharian mereka adalah lingkungan keluarga (dalam hal ini ayah dan ibu) serta lingkungan teman sebaya (Hurlock, 1980). Demikian pula dalam masalah seks, pengaruh keluarga dan teman sebaya amat menentukan keserbabolehan remaja (Reiss, dalam Reiss \& Miler, 1979, dalam Etikariena). Sebagai sumber informasi, kedua lingkungan yang menjadi acuan remaja tersebut memiliki nilai-nilai yang berbeda. Kelu- 
arga (ayah \& ibu) merupakan kelompok acuan yang negatif sedangkan teman adalah kelompok acuan positif untuk keserbabolehan dalam perilaku seks pranikah. Hanya saja ada kecenderungan bahwa orang tua lebih tertutup untuk masalah-masalah yang berkaitan dengan seks. Akibatnya, remaja mencoba mencari akses lain untuk mendapatkan pengetahuan tentang seks.

Remaja mendapatkan pengetahuannya dari teman, buku porno, majalah, atau sumber lain yang tidak dapat dipastikan keakuratannya mengenai seks. Bahkan, ada gejala berkembangnya pengetahuan dan isu populer mengenai seks (mitos), di kalangan remaja. Mitosmitos tersebut cenderung mendorong perilaku seksual pranikah, yang disertai dengan alasan yang dibuat semasuk akal mungkin. Informasi yang benar, namun cenderung mencegah, ditolak dengan bermacam pembenaran. Adalah suatu ironi, di saat remaja sedang mengalami perkembangan seksual dan membutuhkan informasi yang tepat mereka malah dijauhkan dari informasi-informasi tersebut sehingga memilih mempercayai mitos-mitos yang dapat menjerumuskan mereka.

Hasrat untuk melakukan hubungan seksual umumnya terjadi di antara mereka yang telah meningkat remaja, menuju masa dewasa. Hal ini sangat mungkin terjadi mengingat pada saat seseorang memasuki masa remaja mulai timbul dorongan-dorongan seksual didalam dirinya dan minat mereka membina dalam hubungan sosial terfokus pada lawan jenis (Hurlock, 1973, dalam Haryati). Melakukan hubungan seks sebelum menikah (premarital sexual) merupakan salah satu bentuk perilaku seksual yang dapat muncul sehubungan dengan adanya dorongan seksual dan kebutuhan sosial dalam diri remaja.

Menurut Conger (1991, dalam Haryati), faktor yang mempengaruhi minat, tingkah laku, dan sikap remaja terhadap hubungan premarital seksual adalah lingkungan tempat tinggal. Masalah yang muncul dalam kehidupan remaja kota besar tidak terlepas dari munculnya perubahan-perubahan yang terjadi di kota. Penjelasan mengenai kehidupan penduduk kota tidak saja dilihat dari perilaku yang tampak, tetapi juga proses mental yang dialami individu. Dalam hal ini Stanley Milgram (1979, dalam Haryati) mengajukan konsep 'overload' dapat digambarkan dengan keadaan seperti; bising, lalu lintas padat, penduduk yang padat, dan pemukiman yang tidak teratur.
Hasrat untuk melakukan hubungan seksual umumnya terjadi diantara mereka yang telah meningkat remaja, menuju masa dewasa. Hal ini sangat mungkin terjadi mengingat pada saat seseorang memasuki masa remaja mulai timbul dorongan-dorongan seksual didalam dirinya dan minat mereka membina dalam hubungan sosial terfokus pada lawan jenis (Hurlock, 1980).

Cara para remaja berpacaran dewasa ini berkisar dari melakukan ciuman bibir, raba-raba daerah sensitif, saling menggesekan alat kelamin (petting) sampai ada pula yang melakukan sanggama. Dari berbagai penelitian menunjukkan perilaku seksual pada remaja mempunyai korelasi dengan sikap remaja terhadap seksualitas. Penelitian Sahabat Remaja tentang perilaku seksual di empat kota menunjukkan bahwa 3,6\% remaja di kota Medan; 8,5\% remaja di kota Yogyakarta; 3,4\% remaja di kota Surabaya dan 31,1\% remaja kota Kupang telah terlibat hubungan seks secara aktif.

Penelitian yang pernah dilakukan Pusat Penelitian Kependudukan UGM menemukan $33,5 \%$ responden laki-laki di daerah perkotaan di Bali pernah berhubungan seks, sedangkan di daerah pedesaan di Bali mencapai 23,6\%. Di Yogyakarta kota sebesar $15,5 \%$ sedangkan di pedesaan 0,5\%. (Tito, "Potret Remaja dalam Data", Harian Kompas, 3 Agustus 2001, hlm. 38, dalam Tafal) .

Sebuah baseline survai di Semarang yang melibatkan 127 orang responden, yang dilakukan Pilar-PKBI Jawa Tengah yang bekerjasama dengan Tim Embrio 2000, pada tahun 2000 di Semarang menujukkan bahwa $48 \%$ responden meraba daerah sensitif saat berpacaran, $28 \%$ responden telah melakukan petting dan 20\% melakukan hubungan seksual. Yang lebih memprihatinkan adalah bahwa hubungan seks di kalangan remaja tidak dilakukan secara aman. 61,5\% responden yang sudah melakukan hubungan seksual tidak menggunakan alat kontrasepsi (Guntoro Utamadi, "Remaja dan Kecelakaan", Harian Kompas, 5 April 2002, hlm. 35, dalam Tafal). Dua puluh tahun yang lalu, hanya 1,2\%-9,6\% setuju hubungan seksual sebelum menikah. Sepuluh tahun kemudian angka itu naik menjadi $17 \%$ setuju, bahkan ada 12,2\% remaja setuju free sex (Tito, "Potret Remaja dalam Data", Harian Kompas, 3 Agustus 2001, hlm. 42, dalam Tafal).

Pembahasan mengenai perilaku seks dan pacaran yang terjadi pada remaja seringkali melibatkan berbagai faktor, baik itu faktor internal 
maupun faktor eksternal. Faktor internal akan sangat erat kaitannya dengan remaja itu sendiri yang melibatkan masalah pemahaman remaja terhadap perilaku seksual. Sementara faktor eksternal adalah faktor lingkungan. Faktor eksternal tersebut melibatkan peran orang-orang dewasa termasuk orang tua dan guru, serta teman-teman sebaya yang lebih berpengaruh terhadap pola perilaku seks pada masa remaja.

Hasil-hasil survai dan penelitian yang telah dilakukan oleh banyak ahli tersebut begitu mencengangkan mengingat bangsa Indonesia selama ini dikenal sebagai bangsa yang taat beragama. Perilaku seks itu bukan hanya melibatkan remaja yang ada di perkotaan namun juga sudah merambah ke pedesaan. Remaja yang melakukan perilaku seks itu juga kerap terjadi di kalangan pelajar, terutama siswa-siswi SMA, tak terkecuali siswa-siswi Madrasah Aliyah Negeri (MAN).

Demikian pula dengan penelitian terhadap perilaku seksual yang dalam hal ini termasuk pegangan tangan, ciuman, hingga melakukan hubungan badan, dan lain sebagainya, jika merujuk kepada data yang telah diuraikan sebelumnya, telah banyak dilakukan oleh para peneliti yang lain. Namun, apakah perilaku seks itu terjadi secara umum pada kalangan remaja khususnya di kalangan siswa-siswi SMA dan MAN? Pertanyaan seperti ini perlu digali kembali mengingat perilaku seks remaja semakin hari semakin banyak macam dan ragamnya.

Oleh sebab itu, penelitian yang akan digali dalam hal ini tidak akan diarahkan pada perilaku seks pranikah siswa-siswi SMA, melainkan akan difokuskan pada masalah sikap siswa-siswi SMA itu sendiri terhadap perilaku seks pranikah, yakni bagaimana mereka menyikapi perilaku seks pranikah tersebut?, apakah mereka menyikapinya secara positif atau negatif.

Adapun siswa-siswi SMA yang akan diteliti dalam penelitian ini adalah siswa-siswi SMAN "X" dan siswa-siswi MAN "Y" Bandung. Pengambilan siswa-siswi SMAN "X" dan MAN "Y" Bandung sebagai subjek penelitian ini lebih didasarkan pada pertimbangan sebagai studi perbandingan mengingat ada beberapa perbedaan diantara kedua kelompok subjek tersebut.

Jika dilihat dari segi kurikulum pelajarannya, kurikulum SMA jelas berbeda dengan kurikulum Madrasah Aliyah. Perbedaan terse- but sangat mencolok pada kurikulum agamanya. Siswa-siswi SMA secara umum lebih banyak mengenyam pendidikan umum dan hanya sedikit saja jam pelajaran yang diberikan untuk pendidikan keagamaan. Sebaliknya, siswa-siswi Madarasah Aliyah memperoleh pendidikan keagamaan yang cukup dibanding di sekolahsekolah umum seperti pelajaran aqidah akhlak, bahasa Arab, sejarah kebudayaan Islam, piqih, Qur'an- Hadist dan lain sebagainya. Oleh sebab itu, perbedaan ini menjadi alasan utama dilakukannya penelitian ini.

Selain itu, perbedaan kondisi lingkungan diduga bisa jadi merupakan hal yang membedakan kedua kelompok subjek dalam penelitian ini. Berdasarkan wawancara pendahuluan dengan 12 orang siswa-siswi SMAN "X", diketahui bahwa pada umumnya siswa-siswi SMAN "X" beranggapan bahwa perilaku seperti pegangan tangan dan merangkul itu sudah dianggap hal yang sudah lumrah atau dianggap biasa saja, kalau melakukan ciuman 4 orang siswa beranggapan bahwa teman-teman sebayanya rata-rata sudah pernah melakukannya khususnya bagi yang sudah memiliki pacar, mereka melakukannya dengan alasan ingin menunjukkan perasaan yang sesungguhnya, dan terhanyut oleh suasana. Sementara 2 orang siswa beranggapan bahwa perilaku seks pranikah zaman sekarang ini sudah tidak tabu lagi untuk dibicarakan atau didiskusikan, malahan di kalangan remaja sudah menjadi pembahasan yang dianggap biasa. Menurut 4 orang siswa, alasan orang melakukan seksual sebelum menikah adalah karena pengaruh lingkungan, dan untuk membuktikan cintanya kepada pacarnya.

Sedangkan pendapat dari 12 orang siswa-siswi MAN "Y" Bandung, berdasarkan keterangan bahwa pada dasarnya terdapat perbedaan pandangan mengenai masalah pegangan tangan dan merangkul yang sudah dianggap biasa, karena mereka tidak mengetahui bahwa pegangan tangan dan merangkul sudah dianggap sebagai perilaku seks, tetapi hampir semua siswa menyatakan bahwa pegangan tangan dan juga merangkul adalah suatu perilaku yang termasuk perbuatan zinah yang tidak sepantasnya untuk dilakukan. Untuk 2 orang siswa perempuan menyatakan bahwa di sekolahnya tersebut tidak terdapat siswa hamil di luar nikah, mereka beranggapan bahwa perilaku seks itu sangat tabu dan tidak layak untuk dilakukan oleh seumurannya. Apabila ada yang melakukan perilaku seks, itu diakibatkan karena ku- 
rangnya pengetahuan keagamaan dan salah mencari teman serta salah bergaul. Tetapi untuk sebagian siswa laki-laki yang diwawancarai yaitu sebanyak 3 orang menyatakan bahwa seks pranikah harus dihindari. Adanya kasus siswa hamil diluar nikah, menurut siswa tersebut hal demikian disebabkan karena perempuannya yang kecentilan yang membuat laki-laki menjadi tergoda. Dari paparan tersebut tampak bahwa perilaku seks pranikah tidak hanya terjadi di SMA tetapi juga di MAN, tetap ada indikasi perbedaan sikap diantara siswa SMAN "X" dengan MAN "Y" Bandung. Namun apakah perbedaannya signifikan atau tidak, tanpaknya harus diteliti lebih lanjut.

Oleh karena itu peneliti tertarik untuk melakukan penelitian mengenai perbandingan tentang sikap terhadap perilaku seks pranikah antara siswa SMAN "X" dengan siswa MAN "Y" Bandung.

\section{Remaja}

Masa remaja sebagai salah satu periode dalam rentang kehidupan manusia yang memiliki beberapa keunikan tersendiri. Keunikan tersebut bersumber dari kedudukan masa remaja sebagai periode transisional antara masa kanak-kanak dan masa dewasa. Remaja atau adolescence berasal dari kata latin adolescere yang berarti "tumbuh menjadi dewasa". Istilah adolescence seperti yang dipergunakan pada saat ini, mempunyai arti luas mencakup kematangan aspek mental, emosional, sosial, dan fisik. Piaget mengungkapkan pandangan ini dengan mengatakan :

"Secara psikologis, masa remaja adalah usia dimana individu berintegrasi dengan masyarakat dewasa, usia dimana anak tidak lagi merasa di bawah tingkat orang yang lebih tua melainkan berada dalam tingkatan yang sama, sekurangkurangnya dalam masalah hak... Integrasi dalam masyarakat (dewasa) mempunyai banyak aspek afektif, kurang lebih berhubu-ngan dengan masa puber... termasuk juga perubahan intelektual yang mencolok... trans-formasi intelektual yang khas dari cara berpikir remaja ini memungkinkannya untuk mencapai integrasi dalam hubungan sosial orang dewasa yang kenyataanya merupakan ciri khas yang umum dari periode perkembangan ini (Hurlock, 1980 : 206)".
Remaja (Adolescence) diartikan sebagai masa perkembangan transisi antara masa anak, masa dewasa yang mencangkup perubahan biologis, kognitif dan sosial-emosional. Ciri yang menonjol pada masa ini adalah perkembangan fisik yang cepat mencapai bentuk tubuh orang dewasa, perubahan dalam intelektual (kognitif), harapan-harapan baru akan peran sebagai orang dewasa, hubungan interpersonal yang baru dan tanggung jawab sosial yang lebih matang. Remaja dimulai pada usia 10-13 tahun dan berakhir 18-22 tahun (Santrock, 2003: 26).

Adapun Zakiah Darajat (1996: 69) mengartikan remaja sebagai masa perubahan yang ditempuh seseorang dari anak-anak menuju dewasa, atau dapat di katakana bahwa masa remaja adalah perpanjangan masa anak-anak sebelum mencapai masa dewasa dan masa remaja itu tidak sama panjangnya antara satu masyarakat dengan masyarakat yang lainnya. Selain itu Zakiah Darajat mengartikan masa remaja adalah masa yang penuh kegoncangan jiwa, masa berada dalam peralihan atau di atas jembatan goyang, yang menghubungkan masa anak-anak yang penuh kebergantungan dengan masa dewasa yang matang dan berdiri sendiri.

Menurut Hall (dalam Sarwono, 2006: 24) masa remaja adalah masa badai-tekanan ( $S t$ rom and stress), yang mencerminkan kebudayaan modern yang penuh gejolak akibat pertentangan nilai-nilai. Hall berpendapat bahwa mendidik anak harus dengan cara memberinya kebebasan seluas-luasnya, karena perkembangan jiwa manusia banyak dipengaruhi oleh lingkungannya, melainkan sudah di gariskan oleh alam sendiri.

Pada masa remaja juga berlangsung proses-proses perubahan secara biologis, psikologis dan sosiologis, masa remaja sering dirasakan sebagai masa yang lebih sulit dibandingkan dengan masa-masa yang lainnya. Kondisi ini dipengaruhi oleh keadaan individu yang banyak mengalami perubahan dengan dirinya, sehingga selain harus menyesuaikan diri dengan perubahan yang dialaminya, remaja juga harus beradaptasi dengan tuntutan lingkungan, seringkali remaja dihadapkan pada tuntutan-tuntutan yang terkadang saling bertentangan baik dari orang tua, guru, teman sebaya maupun masyarakat sekitarnya. Hal ini seringkali membingungkan remaja, karena masing-masing memberikan tuntutan yang berbeda tergantung pada nilai, norma, atau standar yang digunakan masing-masing. 
Hurlock (1980) membagi masa remaja menjadi awal masa remaja dan akhir masa remaja. Awal masa remaja berlangsung kirakira dari usia 13 tahun sampai 16 tahun atau 17 tahun, dan akhir masa remaja bermula dari usia 16 tahun atau 17 tahun sampai dengan 18 tahun, yaitu usia matang secara hukum.

Menurut Tanner (dalam Hurlock, 1980), masa remaja merupakan periode yang penting karena rentang usia 12 sampai 18 tahun merupakan tahun kehidupan yang penuh kejadian sepanjang menyangkut pertumbuhan dan perkembangan. Perkembangan fisik yang cepat dan penting disertai dengan cepatnya perkembangan mental yang menimbulkan perlunya penyesuaian mental dan perlunya membentuk sikap, nilai, dan minat baru.

Menurut Konopka (Pikunas, 1976, dalam Yusuf 2002:184) masa remaja ini meliputi remaja awal 12-15 tahun, masa remaja madya 15-18 tahun, dan remaja akhir 19-22 tahun.

Zakiah Darajat (1996: 114) membagi masa remaja pada dua bagian, yang pertama masa remaja awal, usia antara 13-16 tahun, dimana pertumbuhan jasmani dan kecerdasan berjalan sangat cepat, yang kedua adalah masa remaja akhir, usia antara 17-21 tahun, yang merupakan pertumbuhan atau perubahan terakhir dalam pembinaan pribadi dan sosial.

Kendatipun bermacam-macam usia yang ditentukan sebagai batas yang menentukan masa remaja, namun pada umumnya ahli-ahli mengambil patokan kurang lebih antara 13-21 tahun untuk usia remaja, namun dalam bidang kematangan beragama usia itu oleh ahli jiwa agama diperpanjang lagi sampai 24/25 tahun, sedangkan kemantapan beragama biasanya dicapai pada umur 24 tahun (Darajat, 1996: 71).

Sedangkan menurut Sarwono (2006: 14) bahwa pedoman dalam pembatasan remaja Indonesia adalah antara 11-24 tahun dan belum menikah, dengan pertimbangan sebagai berikut:

Usia 11 tahun adalah usia dimana pada umumnya tanda-tanda seksual sekunder mulai tampak (kriteria fisik). Di banyak masyarakat Indonesia, usia 11 tahun sudah di anggap akil balig, baik menurut adat maupun agama, sehingga masyarakat tidak lagi memperlakukan mereka sebagai anak-anak (kriteria sosial).

Pada usia tersebut mulai ada tanda-tanda penyempurnaan perkembangan jiwa, seperti tercapainya identitas diri (ego identity, menurut Erik Erikson), tercapainya fase genital dari perkembangan psikoseksual (menurut Freud) dan tercapainya puncak perkembangan kognitif (Piaget) maupun moral (Kohlberg). Batas usia 24 tahun, merupakan batas maksimal yaitu memberi peluang bagi mereka yang sampai batas usia tersebut masih menggantungkan diri pada orang tua, belum mempunyai hak-hak penuh sebagai orang dewasa (secara adat/ tradisi), belum dapat memberikan pendapat sendiri dan sebagainya. Dengan perkataan lain, orang-orang yang sampai batas usia 24 tahun belum dapat memenuhi persyaratan kedewasaan secara sosial maupun psikologi, masih dapat digolongkan remaja. Golongan ini cukup banyak terdapat di Indonesia, terutama dikalangan masyarakat kelas menengah ke atas yang mempersyaratkan berbagai hal (terutama pendidikan setinggi-tingginya) untuk mencapai kedewasaan. Akan tetapi dalam kenyataanya cukup banyak pula orang yang mencapai kedewasaannya sebelum usia tersebut

Dalam definisi di atas, status perkawinan sangat menentukan, karena arti perkawinan masih sangat penting dimasyarakat kita secara menyeluruh, seorang yang sudah menikah pada usia berapapun dianggap dan diperlakukan sebagai orang dewasa penuh baik secara hukum maupun dalam kehidupan masyarakat dan keluarga. Oleh karena itu definisi remaja disini dibatasi khusus untuk yang belum menikah.

Dalam batasan di atas, ada enam penyesuaian diri yang harus dilakukan remaja sebagai berikut: 1) Menerima dan mengintegrasikan pertumbuhan badannya dalam kepribadiannya, 2) Menentukan peran dan fungsi seksualnya yang adekuat dalam kebudayaan tempatnya berada, 3) Mencapai kedewasaan dengan kemandirian, kepercayaan diri, dan kemampuan untuk menghadapi kehidupan, 4) Mencapai posisi yang diterima masyarakat, 5) Mengembangkan hati nurani, tanggung jawab, moralitas, dan nilai-nilai yang sesuai dengan lingkungan dan kebudayaan, 6) Memecahkan problem-problem nyata dalam pengalaman sendiri dalam kaitannya dengan lingkungan (Carballo, 1978:250, dalam Sarwono, 2006:16).

Dari pendapat-pendapat yang telah diuraikan diatas dapat disimpulkan bahwa remaja adalah usia dimana individu tidak merasa dibawah ikatan orang-orang yang lebih tua melainkan berada pada tingkatan yang sama dimana remaja mulai membangun perasaan identitas diri dan perasaan berharga, adaptasi pada kemampuan intelektual yang lebih ma- 
tang. Masa remaja juga merupakan masa penuh gejolak emosi dan ketidakseimbangan, sehingga remaja mudah terkena pengaruh dari lingkungan.

Masa remaja adalah masa peralihan dari anak-anak ke dewasa, bukan dalam artian psikologis, tetapi juga fisik. Bahkan perubahanperubahan fisik yang terjadi itulah yang merupakan gejala primer dalam pertumbuhan remaja. Sementara itu perubahan-perubahan psikologis muncul antara lain sebagai akibat dari perubahan-perubahan fisik itu. Diantara perubahan-perubahan fisik itu, yang terbesar pengaruhnya pada perkembangan jiwa remaja adalah pertumbuhan tubuh (badan menjadi semakin panjang dan tinggi). Selanjutnya mulai berfungsinya alat-alat reproduksi (ditandai dengan haid pada wanita dan mimpi basah pada laki-laki) dan tanda-tanda seksual sekunder yang tumbuh. Menurut Yusuf (2002:194) perkembangan seksualitas remaja ditandai dengan dua ciri yaitu ciri-ciri seks primer dan ciri-ciri seks sekunder.

Pada masa remaja pria ditandai dengan sangat cepatnya pertumbuhan testis, yaitu pada tahun pertama dan kedua, kemudian tumbuh secara lebih lambat, dan mencapai ukuran matangnya pada usia 20 atau 21 tahun. Sebenarnya testis ini telah ada sejak kelahiran, namun baru $10 \%$ dari ukuran matangnya. Setelah testis mulai tumbuh, penis mulai bertambah panjang, pembuluh mani dan kelenjar prostat semakin membesar. Matangnya organ-organ seks tersebut, memungkinkan remaja pria (sekitar 14-15 tahun) mengalami "mimpi basah" (mimpi berhubungan seksual).

Pada remaja wanita, kematangan organorgan seksnya ditandai dengan tumbuhnya rahim, vagina, dan ovarium (indung telur) secara cepat. Ovarium menghasilkan ova (telur) dan mengeluarkan hormon-hormon yang diperlukan untuk kehamilan, menstruasi dan perkembangan sekunder. Pada masa inilah (sekitar usia 11-15 tahun), untuk pertama kalinya remaja wanita mengalami "menarche" (menstruasi pertama). Peristiwa "menarche" ini diikuti oleh menstruasi yang terjadi dalam interval yang tidak beraturan. Untuk jangka waktu enam bulan sampai satu tahun atau lebih, ovulasi mungkin tidak selalu terjadi. Menstruasi awal sering disertai dengan sakit kepala, sakit punggung, dan kadang-kadang kejang, serta merasa lelah, depresi dan mudah tersinggung.
Ciri-ciri atau karakteristik seks sekunder pada masa remaja, baik pria maupun wanita. Pada wanita tumbuh rambut pubik atau bulu kapok sekitar kemaluan dan ketiak, bertambah besar buah dada, bertambah besarnya pinggul. Pada pria tumbuh rambut pubik atau bulu kapok sekitar kemaluan dan ketiak, terjadi perubahan suara, tumbuh kumis, tumbuh jakun.

Dikatakan juga bahwa hormon genadotropic mulai positif ada dalam air seni. Hormon inilah yang bertanggung jawab sebagian pada pertumbuhan tanda-tanda seksual dan bertanggung jawab penuh dalam produksi sel telur dan spermatozoa (Muss, 1968:8, dalam Sarwono, 2006:52).

Perubahan-perubahan fisik itu menyebabkan kecanggungan bagi remaja karena ia harus menyesuaikan diri dengan perubahan-perubahan yang terjadi pada dirinya. Pertumbuhan badan yang mencolok, misalnya pembesaran payudara yang cepat membuat remaja merasa tersisih dari teman-temannya. Demikian pula dalam menghadapi haid dan ejakulasi yang pertama, remaja perlu mengadakan penyesuaian-penyesuaian tingkah laku. Penyesuaian itu tidak selalu dapat dilakukannya dengan mulus, terutama jika tidak ada dukungan dari orang tua.

\section{Perilaku Seks Pranikah}

Perilaku seksual menurut Sarlito (2006: 142) adalah segala tingkah laku yang didorong oleh hasrat seksual baik dengan lawan jenisnya maupun dengan sesama jenis. Bentuk-bentuk tingkah laku ini bisa bermacam-macam, mulai dari perasaan tertarik sampai dengan tingkah laku berkencan, bercumbu, dan bersenggama. Objek seksualnya berupa oranglain, orang dalam khayalan, dan diri sendiri. Sebagian dari tingkah laku itu memang tidak berdampak apaapa terutama tidak ada akibat fisik atau sosial yang dapat ditimbulkannya.

Pada umumnya masalah seks ini bisa sedemikian mengganggu bukan saja bagi orang tua atau orang dewasa yang merasa bertanggung jawab terhadap para remaja melainkan buat remaja itu sendiri, karena masa transisi itu sendiri sudah merupakan masalah remaja, sehingga dapat dikatakan bahwa wajar jika remaja itu bermasalah. Walaupun demikian berbagai usaha tetap dilakukan untuk mengetahui faktor, khususnya apa yang berpengaruh dalam 
masa transisi ini sehingga remaja itu mengetahui berbagai masalah tentang seks. Namun pada kenyataannya banyak remaja yang tidak mengetahui seluk beluk masalah seks tersebut. Mereka mulai mencari tahu berbagai informasi mengenai seks, namun banyak dari mereka yang merasa malu untuk bertanya kepada orang tua atau guru. Sebaliknya orang tua atau guru pun merasa canggung dan kesulitan dalam memberikan pengarahan tentang seks sehingga mereka mencari informasi seks dari sumber-sumber yang kadang kurang dapat dipertanggung jawabkan.

Menurut Harlock (1980: 226) hanya sedikit remaja yang berharap bahwa seluk beluk seks dapat dipelajari dari orang tuanya. Oleh karena itu, remaja mencari berbagai sumber informasi yang mungkin dapat diperoleh, misalnya karena higiene seks di sekolah atau perguruan tinggi, membahas dengan teman-teman, buku-buku tentang seks, atau mengadakan percobaan dengan cara masturbasi, bercumbu, atau bersenggama.

Berdasarkan beberapa penelitian yang dilakukan oleh Nass \& Kkukles (dalam Sarlito 1997: 160), bentuk perilaku seksual yang dilakukan remaja pada umumnya berupa: Memegang (genital stimulation), merupakan aktivitas seksual yang menimbulkan rangsangan seksual berupa sentuhan atau belaian dan remasan tangan dengan tangan, tangan dengan tubuh, tangan dengan payudara, tangan dengan pinggul, tangan dengan kelamin. Ciuman, merupakan aktivitas seksual yang menimbulkan rangsangan berupa sentuhan bibir dengan bibir, bibir dengan payudara/dada. Pelukan, merupakan aktivitas seksual yang menimbulkan rangsangan seksual berupa rangkulan tangan dengan tubuh. Petting (bercumbu), merupakan aktivitas seksual yang menimbulkan rangsangan seksual dengan menempelkan alat kelamin tanpa membuka pakaian. Senggama, merupakan aktivitas seksual yang menimbulkan rangsangan seksual dengan cara memasukan alat kelamin laki-laki kedalam alat kelamin perempuan.

Dengan tercapainya tugas-tugas perkembangan diharapkan remaja dapat menjalani masa transisi kehidupan seksualnya. Remaja juga diharapkan dapat mencapai kehidupan seksual secara dewasa yaitu memiliki kemampuan untuk mengendalikan dorongan-dorongan seksual serta dapat mengekspresikannya melalui caracara yang dapat diterima oleh masyarakat.
Disamping itu remaja juga diharapkan memiliki nilai-nilai sebagai pegangan dalam menjalani kehidupan seksualnya.

Gagasan kuat mengenai benar dan salah sehubungan dengan perilaku seksual menyertai perubahan-perubahan sikap. Perilaku seksual yang dianggap remaja "benar" artinya menjauhi segala perilaku tersebut maka akan disertai dengan sikap yang baik, sebaliknya perilaku seksual yang dianggap salah artinya mendekati segala perilaku seksual akan disertai dengan sikap yang kurang baik.

Sikap memiliki evaluasi positif dan negatif yang bersifat emosional yang disebabkan oleh komponen afektif, pengetahuan dan perasaan tadi menghasilkan tingkah laku tertentu. Objek yang pertama dihadapi pertama-tama berhubungan dengan pemikiran, penalaran seseorang, sehingga komponen kognitif melukiskan objek tersebut. Komponen konatif merupakan kecenderungan bertingkah laku, yaitu bentuk kesediaan bertingkah laku sesuai dengan sikapnya. Bila individu memilki sikap positif terhadap suatu objek, maka ia akan memberi reaksi menerima atau mendukung objek tersebut. Jika sikapnya negatif terhadap objek, maka ia akan cenderung menghindari.

Apabila hal tersebut dioperasionalkan, dimana ketika remaja MAN Y mendapatkan informasi dari suatu sumber yang benar serta dengan wawasan keagamaan yang lebih banyak didapatnya maka remaja akan memperoleh pengetahuan atau informasi baru bahwa misalnya ketertarikan lawan jenis merupakan suatu hal yang wajar terjadi di usia remaja atau kencan merupakan upaya yang dilakukan seseorang untuk saling mengenal pasangan masing-masing, sementara intercourse hanya boleh dilakukan seseorang yang telah menikah saja (kognitif). Melalui pengetahuan atau informasi yang diperolehnya ini menimbulkan penilaian tertentu akan perilaku seks pranikah. Sehingga dengan adanya pengetahuan, pandangan, atau penilaian tertentu yang muncul pada diri remaja yang akan menentukan kecenderungan remaja untuk tidak menyetujui (afektif) dan tidak mau terlibat dalam perilaku seks pranikah seperti intercourse (konatif) yang pada akhirnya pada diri remaja terbentuklah sikap yang negatif terhadap perilaku seks pranikah tersebut.

Sebaliknya, remaja SMAN "X" dengan kurangnya pengetahuan agama sangat memungkinkan remaja untuk mendapat pengetahuan 
tentang seks dari sumber yang lain yang belum tentu benar misalnya informasi yang menyatakan bahwa perilaku seks pranikah itu merupakan suatu hal yang wajar bahkan sudah dijadikan trend dikalangan remaja maka informasi tersebut akan membentuk suatu pengetahuan baru atau keyakinan dalam diri remaja bahwa perilaku seks pranikah merupakan suatu hal yang lazim atau wajar bila dilakukan oleh remaja seusianya (kognitif). Hal tersebut akan menimbulkan suatu penilaian tertentu dalam diri remaja mengenai perilaku seks pranikah tersebut apakah remaja menjadi senang atau tidak senang terhadap perilaku seks pranikah (afektif). Dengan demikian pengetahuan, pandangan atau penilaian terhadap perilaku seks pranikah tersebut akan menentukan kecenderungan remaja untuk mau melakukan atau bersikap memperbolehkan terhadap adanya perilaku-perilaku seks tersebut bila mereka dihadapkan pada suatu situasi tertentu (konatif), dan pada akhirnya akan membentuk suatu sikap positif terhadap perilaku seks pranikah

Dengan demikian dapat diprediksi jika remaja MAN "X" akan bersikap lebih negatif terhadap perilaku seks pranikah. Sebaliknya remaja SMAN "Y" akan bersikap lebih positif terhadap perilaku seks pranikah.

\section{METODOLOGI PENELITIAN}

Penelitian ini menggunakan metode penelitian komparatif. Menurut Dra. Aswarni Sudjun (Arikunto, 2002:236), dalam penelitian komparasi akan dapat menemukan persamaanpersamaan dan perbedaan-perbedaan tentang benda-benda, orang, prosedur, kerja, ide-ide, kritik terhadap orang, kelompok, terhadap suatu ide atau suatu prosedur kerja.

Populasi dalam penelitian ini adalah subjek yang memenuhi karakteristik yang telah ditentukan yaitu: siswa-siswi kelas XI (jurusan IPA dan IPS yang masih terdaftar) SMAN " $X$ " Bandung yang berjumlah 225 orang, dan siswa-siswi kelas XI (jurusan IPA dan IPS yang masih terdaftar) MAN "Y" Bandung yang berjumlah 320 orang. Teknik sampling yang digunakan dalam penelitian ini adalah proportional sampel, dimana teknik sampling ini dilakukan untuk menyempurnakan teknik sampel berstrata atau sampel wilayah. Adapun jumlah sampel yang digunakan dalam penelitian ini adalah sebanyak $25 \%$ dari siswa-siswi yang sesuai dengan kriteria dari setiap kelas.
Instrumen yang digunakan untuk memperoleh data yang dibutuhkan dalam penelitian ini adalah skala sikap terhadap perilaku seks pranikah yang disusun berdasarkan konsep Nass \& Kukles (dalam Sarlito 1997: 160). Karena data yang dihasilkan berskala ordinal dan berasal dari dua kelompok yang independen, maka perhitungan statistik yang digunakan adalah tes U Mann-Whitney.

\section{HASIL DAN PEMBAHASAN}

\section{Hasil}

Berdasarkan hasil perhitungan yang diperoleh dengan derajat kepercayaan sebesar 95\% $(\alpha=0,05)$ diketahui bahwa $\mathrm{p} \geq \alpha$. Hal ini memiliki arti bahwa $\mathrm{H}_{\mathrm{o}}$ diterima dan $\mathrm{H}_{1}$ ditolak, sehingga dapat dikatakan bahwa tidak terdapat perbedaan sikap terhadap perilaku seks pranikah antara siswa SMAN "X" dengan siswa MAN "Y" Bandung. Namun demikian, hasil yang diperoleh menunjukkan harga $\mathrm{z}$ hitung yang memiliki harga negatif $(-1,082)$ sehingga dapat diartikan bahwa siswa MA$\mathrm{N}$ "Y" Bandung memiliki sikap terhadap perilaku seks pranikah yang lebih positif dibanding siswa SMAN "X". Hal tersebut didukung oleh output SPSS yang menunjukkan rata-rata ranking sikap terhadap perilaku seks pranikah siswa MAN "Y" Bandung lebih besar dibanding siswa SMAN "X" $(71,02>63,61)$.

\section{Pembahasan}

Hasil pengujian terhadap hipotesis penelitian secara statistik menunjukkan tidak adanya perbedaan sikap terhadap perilaku seks pranikah antara siswa SMAN "X" dengan siswa MAN "Y" Bandung. Disamping itu, hasil penelitian juga menunjukkan hasil yang bertolak belakang dengan asumsi peneliti sebelumnya, yaitu bahwa sikap siswa SMAN "X" terhadap perilaku seks pranikah lebih positif dibanding dengan siswa MAN "Y".

Hasil analisis deskriptif menunjukkan adanya perbedaan persentase sikap siswa terhadap perilaku seks pranikah antara siswa SMAN "X" dengan siswa MAN "Y" Bandung, dimana sikap positif terhadap perilaku seks pranikah yang lebih banyak ditemukan yaitu di MAN "Y" dibanding dengan SMAN "X". Demikian pula sebaliknya, sikap negatif terhadap perilaku seks pranikah yang lebih sedikit dite- 
mukan di MAN "Y" dibanding dengan SMA$\mathrm{N}$ "X". Namun perbedaan tersebut secara statistik dianggap tidak signifikan dengan kata lain sikap terhadap perilaku seks pranikah antara siswa SMAN "X" dengan siswa MA$\mathrm{N}$ "Y" Bandung relatif sama. Hal tersebut bisa terjadi, dikarenakan berbagai hal yaitu:

Pertama, Menurut Jensen (dalam Sarlito, 2006:153) masalah seksualitas pada remaja salah satunya bisa muncul karena masalah tersebut dianggap tabu/larangan. Norma-norma agama melarang seseorang untuk melakukan hubungan seks sebelum menikah. Bahkan larangan-larangan tersebut berkembang lebih jauh kepada tingkah laku yang lain, seperti berciuman dan masturbasi. Meskipun muatan mata pelajaran agama di MAN lebih banyak, tetapi tetap terdapat kekurangan. Salah satu kekurangan yang dimiliki suatu institusi agama adalah terkadang penjelasan agama mengenai larangan dari hubungan seks sebelum nikah hanya sebatas bahwa perbuatan tersebut adalah dosa dan dosa itu sangat dibenci Allah SWT serta Allah SWT akan menghukum umatnya yang berdosa di neraka, tanpa ada penjelasan lebih jauh yang dianggap logis. Hal tersebut apabila tidak dijelaskan kepada siswa secara mendalam dengan pendekatan ilmiah yang lebih bisa diterima oleh logika tentunya akan membuat siswa semakin penasaran dan mencari sumber lain yang belum tentu bisa dipertanggungjawabkan.

Kecenderungan pelanggaran makin meningkat oleh karena adanya penyebaran informasi seksual melalui media massa, TV serta teknologi canggih seperti internet, dan lain-lain yang menjadi tidak terbendung lagi. Remaja yang sedang dalam periode ingin tahu dan ingin mencoba, akan meniru apa yang dilihat atau didengarnya dari media massa, khususnya karena mereka pada umumnya belum pernah mengetahui masalah seksual secara lengkap.

Kedua, mata pelajaran agama yang diberikan di MAN yang membahas tentang tata cara pergaulan yang sesuai dengan norma agama hanya satu mata pelajaran yaitu Aqidah Akhlaq. Sedangkan mata pelajaran lainnya seperti Fiqih, SKI, Usul Fiqih, Tafsir, Ilmu Hadist, Tasawuf, Ilmu Kalam serta Qur'an-Hadist, hanya membahas tata cara beribadah, sejarah, penentuan hukum, jalur periwayatan hadits serta alasan diturunkannya salah satu ayat dalam Al-Quran. Masa remaja adalah masa pemberontakan, apabila mereka terlalu banyak dijejali oleh doktrin agama mereka akan melakukan pemberontakan, namun pemberontakan ini terkadang hanya berada dalam sikap tanpa muncul dalam perilaku. Sesuai dengan Wicker (1969 dalam O. Sear 1994: 149), yang mengatakan bahwa sikap tidak selalu berdampak pada perilaku yang dimunculkan. Menurut Hurlock (1980:207-209) remaja menunjukkan sikap yang ambivalensi dalam setiap perubahan. Mereka menginginkan dan menuntut kebebasan, tetapi mereka sering takut bertanggung jawab akan akibatnya dan meragukan kemampuan mereka untuk dapat mengatasi tanggung jawab tersebut.

Ketiga, banyaknya siswa yang memiliki sikap yang lebih positif terhadap perilaku seks pranikah di MAN "Y" menurut dugaan peneliti diakibatkan oleh berbedanya proporsi siswa jurusan IPA dan IPS antara MAN "Y" dan SMAN "X". Berdasarkan data yang diperoleh, mata pelajaran Biologi yang diberikan di kelas IPA membahas mengenai alat dan fungsi reproduksi serta sekilas mengenai berbagai penyakit yang bisa muncul akibat aktivitas seks yang tidak sehat. Secara rinci perbedaan proporsi siswa jurusan IPA dan IPS antara MAN "Y" dan SMAN "X" adalah sebagai berikut:

Tabel Proporsi Siswa Berdasarkan Jurusan

\begin{tabular}{ccccc}
\hline & \multicolumn{4}{c}{ Kelompok Siswa } \\
\cline { 2 - 5 } Jurusan & SMAN “X” & \multicolumn{2}{c}{ MAN" Y" } \\
\cline { 2 - 5 } & $\Sigma$ & $\%$ & $\Sigma$ & $\%$ \\
\hline IPA & 33 & 60 & 30 & 37,5 \\
\hline IPS & 22 & 40 & 50 & 62,5 \\
\hline$\Sigma$ & 55 & 100 & 80 & 100 \\
\hline
\end{tabular}

Tabel tersebut menunjukkan bahwa proporsi siswa yang memilih jurusan IPA lebih banyak terdapat di SMAN "X", kemungkinan mereka mendapatkan pengetahuan lebih banyak tentang alat dan fungsi reproduksi serta penyakit yang bisa muncul akibat aktivitas seks yang tidak sehat, dibandingkan dengan MAN yang kemungkinan hanya sedikit mendapatkan pengetahuan tentang alat dan fungsi reproduksi serta penyakit yang bisa muncul akibat aktivitas seks yang tidak sehat, dikarenakan hanya sedikit siswa yang masuk ke jurusan IPA, dimana IPA lebih banyak memberikan pengetahuan Biologi termasuk penge- 
tahuan tentang alat dan fungsi reproduksi, sedangkan IPS tidak mempelajarinya. Hal tersebut memungkinkan sikap terhadap perilaku seks pranikah siswa SMAN "X lebih negatif dibandingkan dengan siswa MAN "Y"

Sikap seseorang dapat berubah apabila ada informasi baru yang dianggap lebih tepat dan lebih rasional. Sesuai dengan Newcomb, dkk (1985: 121) bahwa pada umumnya sikap kita terhadap suatu objek dapat berubah bila, dari pandangan kita objek itu berubah. Ada dua keadaan khusus perubahan objek yang demikian, mungkin objek itu sendiri memang telah berubah atau, hanya bahwa informasi kita mengenai objek itu yang telah berubah, tanpa ada perubahan yang sesungguhnya pada objek.

Sikap yang dimunculkan oleh seseorang tidak selalu berdampak pada perilaku yang dimunculkan, hal ini bergantung kepada seberapa kuat keyakinan yang dipegang (Wicker, 1969 dalam O. Sear 1994: 149). Kesesuaian antara sikap dengan perilaku yang muncul tergantung pada apakah sikap itu merupakan sikap yang kuat dan jelas atau tidak sehingga konsisten, sebaliknya jika sikap itu lemah dan ambivalen maka akan memunculkan ketidak-konsistenan dengan perilaku yang muncul. Demikian pula, perilaku yang konsisten tidak akan muncul bila komponen afeksi dan kognisi sikap bertentangan seperti diungkapkan oleh Norman. (1975 dalam O. Sear, 1994: 150).

Dengan demikian sikap yang positif terhadap perilaku seks pranikah yang dimunculkan oleh siswa MAN "Y" belum tentu diiringi oleh intensitas perilaku seks pranikah yang negatif. Begitu pula sebaliknya, sikap terhadap perilaku seks yang negatif yang ditunjukkan oleh siswa SMAN "X" belum tentu diiringi oleh intensitas perilaku seks pranikah yang negatif. Semuanya bergantung kepada keyakinan pribadi yang dimiliki serta kekuatan dan konsistensi dari sikap itu sendiri.

\section{SIMPULAN DAN SARAN}

\section{Simpulan}

Berdasarkan hasil analisis dan pembahasan tentang sikap terhadap perilaku seks pranikah antara siswa SMAN "X" dengan siswa MAN "Y" Bandung dapat ditarik simpulan sebagai berikut: Dengan derajat kepercayaan sebesar 95\% $(\alpha=0,05)$ diketahui bahwa $\mathrm{p} \geq \alpha$. Hal ini memiliki arti bahwa $\mathrm{H}_{\mathrm{o}}$ diterima dan
$\mathrm{H}_{1}$ ditolak, sehingga dapat dikatakan bahwa tidak terdapat perbedaan sikap terhadap perilaku seks pranikah antara siswa SMAN "X" dengan siswa MAN "Y" Bandung.

\section{Saran}

Berdasarkan hasil penelitian yang telah dilakukan, dengan memperhatikan keterbatasan-keterbatasan dalam penelitian ini, peneliti mengajukan saran-saran agar dapat dijadikan bahan pertimbangan bagi pihak-pihak yang memerlukannya sebagai berikut:

Bagi siswa, cari informasi yang lebih jelas dan dapat dipertanggung jawabkan mengenai masalah seks pada orang tua, guru, konselor atau LSM yang bergerak dibidang penyuluhan mengenai kesehatan reproduksi, bahaya HIV/AIDS dan sebagainya.

Bagi pihak sekolah, harap menjadi bahan pertimbangan untuk memasukan pendidikan seks (sex education) kedalam pelajaran muatan lokal atau dibahas dalam kegiatan ekstrakulikuler. Karena meskipun sikap tidak selalu diiringi dengan perilaku yang sama, tetapi sikap itu cenderung mengarah pada perilaku yang sama, serta sikap seseorang itu dapat dirubah bila ada informasi baru yang dianggap lebih benar.

Bagi pihak keluarga, supaya lebih terbuka dalam membicarakan masalah seks supaya anak tidak mencari informasi dari sumber lain yang tidak bisa dipertanggungjawabkan.

Bagi penelitian selanjutnya, disarankan untuk menjaring data-data kualitatif lebih banyak lagi sebagai bahan untuk menunjang dan melengkapi hasil data kuantitatif, sehingga dapat menghasilkan analisis yang lebih akurat.

\section{DAFTAR PUSTAKA}

Arikunto, S. (2002). Prosedur Penelitian: Suatu Pendekatan Praktek. Jakarta: Rineka Cipta.

Azwar, S. (2004). Penyusunan Skala Psikologi. Yogyakarta: Pustaka Pelajar Offset.

Azwar, Saefuddin. (2005). Sikap Manusia.Yogyakarta: Pustaka Pelajar Offset.

Darajat, Zakiah. (1996). Ilmu Jiwa Agama, Jakarta: PT. Bulan Bintang.

Departemen Agama RI, Kurikulum Tingkat Satuan Pendidikan (KTSP) MAN Bandung.

Etikariena, Arum. (1998). Hubungan Mitos 
tentang Seksualitas dengan Keserbabolehan Perilaku Seksual Pranikah Pada Remaja "ABG" di Jakarta: http// www.Skripsi-Tesis.com

Friedenberg, Lisa. (1995). Psychological Testing Design, Analysis, and Use. Allyn \& Bacon. Massachusetts.

Haryati, Yuni. (1999). Hubungan dan Kondisi "Overload" dengan Sikap Remaja Terhadap Hubungan Premarital Seksual di Kuningan: http//www.Skripsi-Tesis.com

Hurlock, Elizabeth. (1980). Psikologi Perkembangan (terj). Jakarta: Erlangga.

Nazir, Moh. Ph.D. 1985. Metode Penelitian Ghalia Indonesia. Jakarta.

Newcomb \& dkk. (1985). psikologi Sosial. Edisi Indonesia. CV. Dipenegoro. Bandung

Pemerintah Kota Bandung Dinas Pendidikan. Kurikulum SMAN 26 Bandung tahun ajaran 2006/2007.

Santrock, W. (2003). Adolescence (Perkembangan Remaja), Jakarta: Erlangga.

Sarwono, Sarlito W. (1997). Psikologi Remaja. Edisi 1. Jakarta: PT Raja Grafindo Persada
Sarwono, Sarlito W. (2006). Psikologi Remaja. Jakarta: PT Raja Grafindo Persada

Sears, O. David., Freedman, L. Jonathan., Peplau, L. Anne. (1994). Social antropology Fifth Edition (edisi terjemah: Psikologi Sosial). PT Gelora Aksara Pratama.

Siegel, S. (1997). Statistik Non Parametrik, Diterjemahkan oleh Zanzawi Suyuti \& Landang Simatupang, Jakarta: PT Gramedia.

Sudjana. (1996). Metoda Statistika edisi keenam. Bandung: Tarsito.

Sugiyono. (2007). Metode Penelitian Kuantitatif Kualitatif dan $R \& D$. Bandung: Penerbit Alfabeta.

Sutrisno, Hadi. (2002). Metodologi research. Andi .Yogyakarta.

Tafal, Zarfiel. 2001, Kebutuhan akan informasi dan pelayanan kesehatan reproduksi remaja. www.pkbi.co.id

W.A Gerungan. DR. DIPL. PSYCH. (2002). Psikologi Sosial. Reflika Aditama. Bandung.

Yusuf, Syamsu. 2002, Psikologi Perkembangan Anak dan Remaja. Bandung: PT Remaja Rosdakarya 